\title{
Vertical niche separation of phytoplankton: large-scale mesocosm experiments
}

\author{
Kalle Olli ${ }^{1,2, *}$, Jukka Seppälä ${ }^{3}$ \\ ${ }^{1}$ Institute of Botany and Ecology, University of Tartu, Lai 40, 51005 Tartu, Estonia \\ ${ }^{2}$ Biology Department, Woods Hole Oceanographic Institution Woods Hole, Massachusetts 02543, USA \\ ${ }^{3}$ Finnish Environment Institute, PO Box 140, 00251 Helsinki, Finland
}

\begin{abstract}
Vertical distribution patterns of Heterocapsa triquetra, Mesodinium rubrum, Aphanizomenon sp., Anabaena lemmermannii, Monoraphidium contortum and chlorophyll a were analyzed in large-scale mesocosms extending throughout the euphotic layer and manipulated with low and high levels of mineral nutrient additions. Using an ordination method, quantitative comparisons of the variability in the vertical distribution due to species differences, to experimental treatments, and to inter-annual variation were made. The inter-specific variance component was largest. The significance of inter-specific differences was verified by a randomization test. There was also significant inter-annual variability in the species-specific vertical distribution patterns, but the inter-annual effect was less pronounced than the differences between species. Differences in the nutrient loads to the mesocosm did not have significant effects on species-specific vertical distribution patterns. The results demonstrate that the vertical segregation patterns of phytoplankton are species-specific and robust, not overly sensitive to changes in environmental conditions, but appear to be persistent biological phenomena. The implications of these findings to co-existence, competition, and diversity in the plankton are discussed.
\end{abstract}

KEY WORDS: Vertical distribution $\cdot$ Niche separation $\cdot$ Phytoplankton $\cdot$ Co-existence

\section{INTRODUCTION}

Much of the function and structure of natural phytoplankton communities fundamentally depends on interactions between light limitation and nutrient limitation. It is well known that the relative importance of light and nutrient limitation varies with depth. Commonly, the top of the water column is light-saturated, but phytoplankton growth is limited by low nutrient concentrations. The situation is the reverse with increasing depth. Assuming that each species has its own preferences for nutrients, light and temperature, the questions are: do these species exploit different parts of the vertical resource gradient and do they use vertical separation to inhabit and exploit vertical niches where species-specific requirements are met in

*E-mail: olli@ut.ee the best possible way? If yes, then how consistent is the separation compared to inter-annual variability and changes in environmental conditions?

In natural environments, vertical niche separation can lead to co-existence of closely related species (Sommer 1982, West \& Scanlan 1999) and has thus relevance to competition and species richness. The ways in which species can become vertically separated vary widely (Heaney \& Butterwick 1985), and the populations are liable to re-dispersion by mixing. In a stratified water column, enhanced growth at optimal optical depth can lead to uneven phytoplankton distributions and induce the formation of intermediate maxima of abundance (Lindholm 1992, Gasol et al. 1993). Motility of planktonic micro-organisms, either by active swimming or by buoyancy regulation, provides cells with a powerful strategy to seek an optimal vertical position in the water column within the limits of physical and physiological constraints. Many species also take ad- 
vantage of diel light fluctuations to exploit resources from a wide depth range over the course of a day; this is known as diel vertical migration (DVM) (Eppley et al. 1968, Blasco 1978, Staker \& Bruno 1980, Heaney \& Eppley 1981). For autotrophic micro-organisms the adaptive significance of DVM could be summarized as the exploitation of high levels of irradiance near the surface during the day, where low concentrations of inorganic nutrients would normally limit growth, and nocturnal descent to a layer where readily available nutrients are utilized to fulfill metabolic requirements (Cullen 1985, Jones 1991). The net result is optimization of growth rate within the constraints of the environmental limitations and ecological strategy of the species. The potential range and success of DVM depends on the dispersion by mixing and the speciesspecific absolute swimming speed of the organisms (Throndsen 1973), which is also related to their cell size (Sommer 1988a). Dinoflagellates are generally considered relatively fast swimmers among phytoplankton (Throndsen 1973, Kamykowski \& McCollum 1986, Kamykowski 1995). Several cyanobacterial species are able to change their buoyancy by regulating the relative amount of gas vesicles and ballast carbohydrates within the cells (Klemer 1985, Villareal \& Carpenter 1990, Oliver 1994). One of the fastest swimmers among the primary producers is the phototrophic ciliate Mesodinium rubrum, which can swim up to $5 \mathrm{~mm}$ $\mathrm{s}^{-1}$ (Lindholm 1981), on average an order of magnitude faster than dinoflagellates.

The aim of this study was to demonstrate in a formal, testable way that vertical segregation of phytoplankton is a persistent, robust and species-specific property. The null hypothesis was that any differences in the vertical distribution between species are random in nature and inconsistent. To test the hypothesis, highfrequency sampling of phytoplankton vertical profiles was carried out during a diel cycle in the summers of 1996 and 1998 in mesocosms receiving different nutrient loads. Specific objectives were to demonstrate how the vertical distribution of phytoplankton is affected by (1) motility, (2) differences in nutrient loads, and (3) inter-annual variability. As DVM is often induced by shortage of mineral nutrients in the upper euphotic layer (Heaney \& Eppley 1981, Klemer et al. 1982, Cullen 1985), we expected the vertical migration to be more pronounced in a low-nutrient environment. To give the plankton communities time to adapt to the new nutrient regimes, the vertical profiles were sampled at the end of the second week of the experiments. This study was conducted during 2 large-scale mesocosm experiments in the coastal Baltic Sea. These mesocosm experiments were designed within the COMWEB project, which focused on the response of microbial food-web components of the coastal pelagic community (phytoplankton, bacteria, protozoa, mesozooplankton) to increasing eutrophication.

\section{METHODS}

Experimental set-up. The mesocosm experiments were conducted between July 17 and August 7, 1996, and June 23 and July 13, 1998, in the outer archipelago zone near the Tvärminne Zoological station (University of Helsinki), on the south-western coast of Finland (Stn XII of Niemi 1975). The experimental site has a depth of 20 to $36 \mathrm{~m}$, is relatively sheltered, and is influenced by Baltic surface water (6 to 7 psu) during frequent upwelling events (Niemi 1975, Haapala 1994).

The physical set-up of the experiments was identical in both years. A natural water column was enclosed in 8 transparent enclosures and manipulated with mineral nutrients. Each plastic enclosure (double-layered polyethylene with glass-fiber thread reinforcement in between) had a total volume of $51 \mathrm{~m}^{3}$ (diameter $2.3 \mathrm{~m}$ ) and a total depth of $14 \mathrm{~m}$. The enclosures were fastened to wooden platforms, which were moored in a circular manner ca $30 \mathrm{~m}$ away from a central buoy. The enclosures were loosely covered with polyethylene lids to allow air exchange but prevent contamination by sea birds.

During both experiments, mineral nutrients (ammonium chloride and potassium dihydrogen phosphate) were added daily between 09:00 and 10:00 h, starting from Day 2. An even distribution of these nutrients within the 0 to $12 \mathrm{~m}$ water column was achieved by lowering an open-ended hose to the mesocosm, filling it with the nutrient mixture (diluted into a fixed volume that filled the entire hose), and slowly lifting the hose to the surface with a circular motion. Within any given year, all the mesocosms received different nutrient loads; thus there was no true replication. Earlier similar experiments had showed that the variance in the abundance of individual phytoplankton species between replicate mesocosms was $<10 \%$ (Olli et al. 1996). In the control mesocosms (no nutrient additions), the cell concentrations of micro-phytoplankton species declined to negligible levels. Thus, during both years, 1 low-nutrient load (LN) enclosure and 1 high-nutrient load ( $\mathrm{HN}$ ) enclosure, with balanced added nutrient ratios (molar $\mathrm{N}: \mathrm{P}=16$; concentrations given in Table 1), were used for the vertical distribution study.

Sampling and sample analysis. Sampling was performed during a $24 \mathrm{~h}$ period with $4 \mathrm{~h}$ time intervals starting at 09:00 h on Expt Days 15 and 16 (1996) and 16 and 17 (1998). By this time, clear differences in the phytoplankton community had developed between LN and HN enclosures. The water column from 0 to $12 \mathrm{~m}$ was sampled with a Sormunen type water sampler 
Table 1. Nutrient loads $\left(\mathrm{mmol} \mathrm{m} \mathrm{m}^{-3} \mathrm{~d}^{-1}\right)$ in enclosures where vertical profiles of phytoplankton were sampled. LN: low nutrient load; HN: high nutrient load

\begin{tabular}{|lll|}
\hline Nutrient load & $\mathrm{NH}_{4}$ & $\mathrm{PO}_{4}$ \\
\hline 1996 & & \\
LN & 0.14 & 0.01 \\
$\mathrm{HN}$ & 0.74 & 0.05 \\
1998 & & \\
LN & 0.29 & 0.02 \\
$\mathrm{HN}$ & 0.47 & 0.05 \\
\hline
\end{tabular}

(a $7.5 \mathrm{l}$ volume and $1 \mathrm{~m}$-long tube sampler) with $1 \mathrm{~m}$ depth interval. The contents of each 2 subsequent samples were pooled, totaling 6 composite samples per profile, where each represented $2 \mathrm{~m}$ water-column depth.

Sub-samples for phytoplankton counts $(100 \mathrm{ml})$ were fixed immediately with acid Lugol's solution and kept dark until counting. Aliquots of 25 or $50 \mathrm{ml}$ were counted with a Leica DM IL inverted microscope with phasecontrast optics. The phytoplankton species selected for the study are listed in Table 2 ; species selection was based on their abundance (to facilitate easy counting) and their motility potential based on theoretical size considerations (Sommer 1988a). Aphanizomenon sp. and Anabaena lemmermannii are common filamentous bloom-forming cyanobacteria in the Baltic Sea, capable of buoyancy regulation through gas-vesicle formation. Heterocapsa triquetra is a ubiquitously present dinoflagellate in coastal waters, often forming dense blooms. The coccoid chlorophyte Monoraphidium contortum was selected as a non-motile reference organism. Chlorophyll a (chl) was sampled as another reference parameter to reflect the vertical distribution of bulk phytoplankton. Sub-samples for chl $(50 \mathrm{ml})$ were filtered onto Whatman (GF/F) glass-fiber filters and immediately soaked in $96 \%$ ethanol for $24 \mathrm{~h}$ at room temperature. Chl was analyzed with a spectrofluorometer (Shimadzu RF 5001) using excitation at $431 \mathrm{~nm}$ and emission at $671 \mathrm{~nm}$ with $5 \mathrm{~nm}$ bandwidths.

Table 2. Species of autotrophic micro-organisms which were selected for the vertical distribution study. LN: low nutrient load enclosure; HN: high nutrient load enclosure

\begin{tabular}{|lccccc|}
\hline \multirow{2}{*}{ Species } & \multicolumn{2}{c}{1996} & & \multicolumn{2}{c|}{1998} \\
& LN & HN & & LN & HN \\
\hline Heterocapsa triquetra & $\times$ & $\times$ & & $\times$ & $\times$ \\
Mesodinium rubrum & $\times$ & $\times$ & $\times$ & $\times$ \\
Monoraphidium contortum & $\times$ & $\times$ & & \\
Anabaena lemmermannii & $\times$ & & $\times$ & $\times$ \\
Aphanizomenon sp. & & & $\times$ & $\times$ \\
Chlorophyll a & $\times$ & $\times$ & $\times$ & $\times$ \\
& & & & \\
\hline
\end{tabular}

The spectrofluorometer was calibrated using chlorophyll a standard (Sigma) and an extinction coefficient of $83.4 \mathrm{l} \mathrm{g}^{-1} \mathrm{~cm}^{-1}$ at the red peak of 665 and $666 \mathrm{~nm}$ (Wintermans \& de Mots 1965).

Water-column stratification was assessed using CTD casts inside and outside the mesocosms. Daily irradiance was obtained from the Längden stationary weather station, $8 \mathrm{~km}$ south of the study site. Underwater light profiles were measured every $1 \mathrm{~m}$ from 1 to $10 \mathrm{~m}$ (Li-Cor submersible quatum meter equipped with a cosine collector). During the 1996 experiment, light profiles were measured every second day starting from Day 1 (outside the mesocosms, control with no nutrient additions and 2 nutrient load mesocosms). During the 1998 experiment, light profiles were measured on Expt Days 2 (outside and control) and 4 (outside, control and 3 nutrient load mesocosms). Malfunctioning of the underwater light sensor prevented further measurements during 1998. Samples for dissolved mineral nutrients $\left(\mathrm{NO}_{2}-\mathrm{N}+\mathrm{NO}_{3}-\mathrm{N}, \mathrm{PO}_{4}-\mathrm{P}, \mathrm{NH}_{4}-\mathrm{N}\right)$ were taken daily from a pooled water sample representing the upper 0 to $6 \mathrm{~m}$ layer, and every second day representing the deeper 6 to $12 \mathrm{~m}$ layer, and analyzed according to the method of Grasshoff et al. (1983). All nutrient samples were taken in the morning prior to the daily enrichments.

Data analysis. The depth profiles of the species and chl were analyzed by correspondence analysis (ADE-4; software and documentation: http://biomserv. univ-lyon1.fr). The data were arranged in a matrix with 6 columns corresponding to the 6 sampled depths, which were treated as variables. The rows represented the vertical abundance profiles of phytoplankton species (and chl) at different times. Ordination techniques are very efficient in concentrating the available multidimensional information into a few axes, which explain most of the variance. The data presented here resulted from row-weighted correspondence analysis. Row-weighting involves a linear scaling of the cell abundance in individual profiles so that the sum of cells in each profile will become equal. This eliminates the potential effects of several-fold differences in total abundance and leaves the shape of the profiles as the source of variance. A variety of other ordination techniques (several forms of principal component and correspondence analyses) were tried in parallel. The results appeared to be robust and not dependent on the method used. Correspondence analysis was favored because of the double multiplicative centering of the data table. It considers the departure of each data point from its expected value, i.e. the mean of all the (linearly scaled) species abundances at a given depth. Thus, the average effect of depth is eliminated and the present analysis focuses on the shape of individual vertical profiles relative to the mean of all profiles. The method has been used earlier to analyze the vertical 
distribution of phytoplankton in open water (Olli et al. 1998, Olli 1999).

By correspondence analysis, the 6 discrete depths were reduced to 2 ordination axes, enabling a simultaneous visualization of each depth profile of the species in 2-dimensional space (the first 2 axes accounted for $>80 \%$ of the information). The first ordination axis generally agreed well with the depth gradient, which makes the interpretation of the ordination results more clear. The individual vertical profiles are represented as points on an ordination plane and the relative locations of the points depend only on the shape of the profile. These points can be grouped according to species, sampling time, year, nutrient regime or a combination of these. Grouping of the profiles is based on the hypothesis that it explains a significant amount of the total variance in the data, i.e. that there is something in common among the profiles of the same group.

The hypotheses can be tested statistically by a randomization procedure. First, the between-group variance (i.e. between the centers of gravity of the groups) was calculated. This original variance was then compared against a set of simulated data, which involved random exchange of vertical profiles between the groups, and recalculation of the variance between the group centers of gravity. If the original between-group variance significantly exceeded the simulated variance (when at least 10000 permutations were run), the difference between the original groups could be considered statistically significant. The group differences were considered significant when the proportion of simulations resulting in larger between-group variance than the original one (denoted here as p) was less than 0.05 . It could be interpreted similar to the $p$-value of conventional statistical tests, but is not identical, as it is not based on theoretical probability distributions but on the outcome of simulation runs and is presented here as exact numbers. The randomization procedure provides a formal way to test the underlying hypothe- sis. Hence, it is possible to conclude with a certain amount of confidence that the vertical profiles of 1 species are, or are not, significantly different from those of another species, a conclusion that might be impossible to reach by visual inspection of the vertical profiles.

\section{RESULTS}

\section{Physical conditions}

During our experiment, the hourly means of midday irradiance (11:00 to 13:00 h) ranged from 800 to $900 \mu \mathrm{E}$ $\mathrm{m}^{-2} \mathrm{~s}^{-1}$ (1996) and 800 to $1000 \mu \mathrm{E} \mathrm{m} \mathrm{m}^{-2} \mathrm{~s}^{-1}$ (1999). The average light attenuation coefficient inside the mesocosms was $0.53 \mathrm{~m}^{-1}$ (range 0.46 to $0.64 \mathrm{~m}^{-1}$ ). Most of the variance was explained by light attenuation outside the mesocosms (Pearson correlation coefficient $\mathrm{r}=0.89, \mathrm{p}<0.001, \mathrm{n}=34$ ). Correlation between light attenuation and chl within the mesocosms was not significant $(\mathrm{p}>0.4, \mathrm{n}=34)$. Light attenuation inside the mesocosms was on average $6.9 \%$ higher than that outside. The depth of the euphotic layer (defined as $1 \%$ of surface irradiance at noon time) was $9 \mathrm{~m}$. This corresponds to about $9 \mu \mathrm{E} \mathrm{m} \mathrm{m}^{-2} \mathrm{~s}^{-1}$ at midday.

The initial salinity stratification had almost disappeared by the end of the second week of the mesocosm experiment. The water-column stability within the enclosures arose mainly from temperature stratification, which, due to thermal conductivity through the enclosure walls, closely paralelled that outside the enclosures. In 1996, the surface temperature decreased from $15^{\circ} \mathrm{C}(13: 00 \mathrm{~h}$; Day 15$)$ to $14^{\circ} \mathrm{C}(05: 00 \mathrm{~h}$; Day 16$)$ during the $24 \mathrm{~h}$ period. At the thermocline ( 2 to $4 \mathrm{~m}$ ) the temperature dropped from 14 to $12^{\circ} \mathrm{C}$ and decreased thereafter down to $9-10^{\circ} \mathrm{C}$ at $12 \mathrm{~m}$ depth (Fig. 1). In 1998, CTD casts within the study enclosures were made on Expt Days 14 and 18. During this time period, the surface water temperature increased from 14.5 to

Table 3. Measured mineral nutrient concentrations $(\mu \mathrm{M})$ in the upper and deeper layers of the enclosures during Day 1 (initial values before nutrient additions) and the mean values during Days 14 to 16 (1996) and 15 to 17 (1998). Note the very low molar $\mathrm{N}: \mathrm{P}$ ratios. 0 : concentrations of $\mathrm{NH}_{4}$ below detection limit $(<0.036 \mu \mathrm{M})$

\begin{tabular}{|c|c|c|c|c|c|c|c|c|c|}
\hline Load & Layer (m) & Day $1 \mathrm{NO}_{3}$ & Day $1 \mathrm{NH}_{4}$ & Day $1 \mathrm{PO}_{4}$ & Day 1 N:P & $\mathrm{NO}_{3}$ & $\mathrm{NH}_{4}$ & $\mathrm{PO}_{4}$ & $\mathrm{~N}: \mathrm{P}$ \\
\hline \multicolumn{10}{|l|}{1996} \\
\hline \multirow[t]{2}{*}{ LN } & $0-6$ & 0.09 & 0.04 & 0.21 & 0.6 & 0.12 & 0 & 0.05 & 2.4 \\
\hline & $6-12$ & 0.12 & 0.42 & 0.17 & 3.2 & 0.10 & 0.14 & 0.10 & 2.5 \\
\hline \multirow[t]{2}{*}{$\mathrm{HN}$} & $0-6$ & 0.11 & 0.04 & 0.21 & 0.7 & 0.21 & 0 & 0.03 & 6.3 \\
\hline & $6-12$ & 0.13 & 0.09 & 0.35 & 0.6 & 0.12 & 0.05 & 0.06 & 3.1 \\
\hline \multicolumn{10}{|l|}{1998} \\
\hline \multirow[t]{2}{*}{ LN } & $0-6$ & 0.14 & 0.30 & 0.28 & 1.5 & 0.12 & 0.12 & 0.08 & 3.1 \\
\hline & $6-12$ & 0.15 & 0.38 & 0.32 & 1.7 & 0.11 & 0.15 & 0.14 & 1.8 \\
\hline \multirow[t]{2}{*}{$\mathrm{HN}$} & $0-6$ & 0.13 & 0.33 & 0.24 & 1.9 & 0.16 & 0.10 & 0.11 & 2.4 \\
\hline & $6-12$ & 0.11 & 0.36 & 0.27 & 1.7 & 0.14 & 0.10 & 0.13 & 1.8 \\
\hline
\end{tabular}




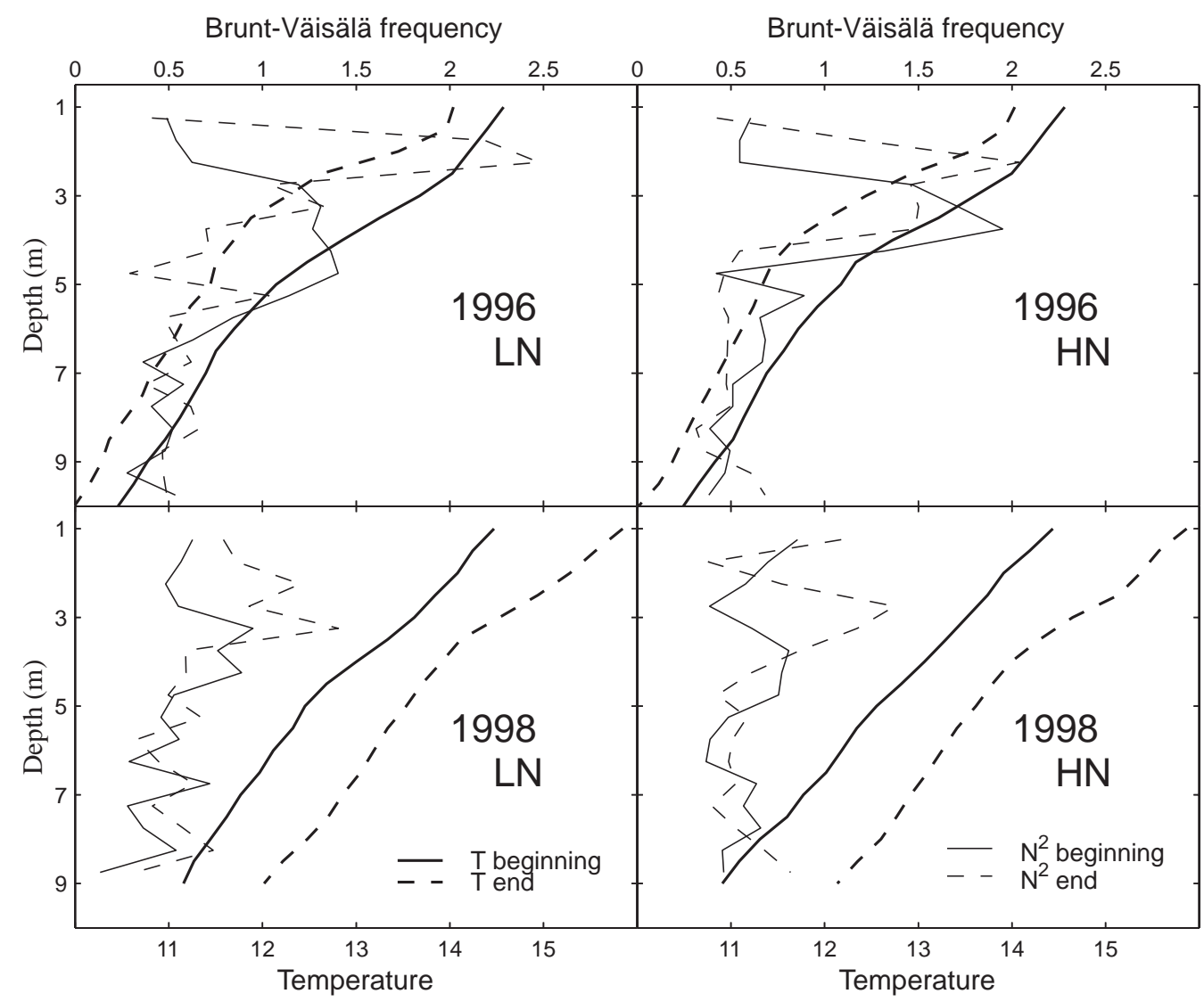

Fig. 1. Profiles of water temperature $\left(T,{ }^{\circ} \mathrm{C}\right.$ ) and water-column stability (Brunt-Väisälä frequency, $\mathrm{N}^{2}$ in $\left.10^{3} \mathrm{rad}^{2} \mathrm{~s}^{-2}\right)$ at the beginning and end of the $24 \mathrm{~h}$ cycle in 1996 and 1998. LN: low nutrient load enclosure; HN: high nutrient load enclosure

$16^{\circ} \mathrm{C}$ (Fig. 1). In 1998 there was no distinct thermocline; temperature decreased gradually from the surface to the bottom layer.

\section{Nutrients}

The initial mineral nutrient concentrations on Day 1, and $3 \mathrm{~d}$ mean concentrations including the days of vertical distribution sampling and $1 \mathrm{~d}$ before, are given in Table 3. Nitrate concentration was low (generally $<0.15 \mu \mathrm{M}$ ) throughout the experiments and there were no significant differences between the layers. In 1996 there was a slight accumulation of nitrate during the third week in the HN enclosure (up to $0.21 \mu \mathrm{M}$ ). Ammonium concentrations were generally around $0.15 \mu \mathrm{M}$, indicating rapid uptake by the phytoplankton. Differences between the upper and deeper layers were minor and inconsistent, except in the LN enclosure during 1996, when ammonium concentrations were generally higher in the deeper layer. In both years, the initial concentration of phosphate was high $(0.16$ to $0.34 \mu \mathrm{M})$, but there was a general decreasing trend down to
0.03-0.09 $\mu \mathrm{M}$ by the end of the experiments. The difference in phosphate concentration between the upper and deeper layers was generally consistent, being higher in the deeper layer. In spite of the balanced nutrient additions (molar $\mathrm{N}: \mathrm{P}=16$ ), phosphate tended always to be in excess (molar N:P generally $<7$ ).

\section{Response of plankton organisms}

Nutrient enrichment invoked a rapid increase in the phytoplankton biomass in both years. The initial mean 0 to 12 m-integrated chl concentrations in 1996 and 1998

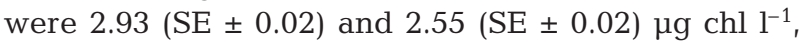
respectively. By the time of the vertical profile sampling, the chl concentrations in the LN and HN enclosures had increased to 9.67 (SE \pm 0.07 ) and 15.94 (SE \pm $0.19) \mu \mathrm{chl} \mathrm{l}^{-1}$ in 1996, and to 5.50 (SE \pm 0.05 ) and $16.92(\mathrm{SE} \pm 0.14) \mu \mathrm{g} \mathrm{chl} \mathrm{l^{-1 }}$ in 1998. In both years the increase in chl concentration was most pronounced during the first week of the experiment. In 1996, the phytoplankton response was mainly attributable to the dominant species Heterocapsa triquetra. In 1998, the 
numbers of $H$. triquetra were low during the first half of the mesocosm experiment, but by Day 16 it dominated the micro-phytoplankton biomass. The filamentous cyanobacteria had a slower response. In 1998, both Aphanizomenon sp. and Anabaena lemmermannii became quite abundant by Day 16. In 1996, Aphanizomenon sp. had a very low biomass and could not be quantified, while $A$. lemmermannii was sufficiently abundant only in the LN enclosure. Mesodinium rubrum had a relatively low abundance in both years, but sufficient to be quantified reliably.

\section{Vertical profiles of chl and phytoplankton}

\section{6 experiment}

In the LN enclosure, the dominant species, Heterocapsa triquetra, was concentrated in the upper layers during the light period, but had a relatively uniform vertical distribution throughout the water column in the dark period (Fig. 2). This was contrasted by the vertical distribution of Mesodinium rubrum, which was more abundant in the deeper layers, during both night and day (Fig. 2). The profiles of Monoraphidium contortum were fairly uniform or decreased slightly with increasing depth (Fig. 2). In contrast, Anabaena lemmermannii was never abundant in deeper layers and had a relatively consistent peak at or near the surface layer (Fig. 2). Chl concentrations increased uniformly towards the surface, although with some fluctuations (Fig. 2). In the HN enclosure, $H$. triquetra displayed a surface aggregation throughout the $24 \mathrm{~h}$ period, and also a deep aggregation of varying magnitude (Fig. 3). The profiles of $M$. rubrum were quite similar to those in the LN enclosure, being characterized by aggregations in the middle and deeper layers and avoidance of the surface layer (Fig. 3). The vertical profiles of $M$. contortum varied without any notable pattern (Fig. 3). The shape of vertical profiles of chl (Fig. 3) followed those of the dominant species H. triquetra.
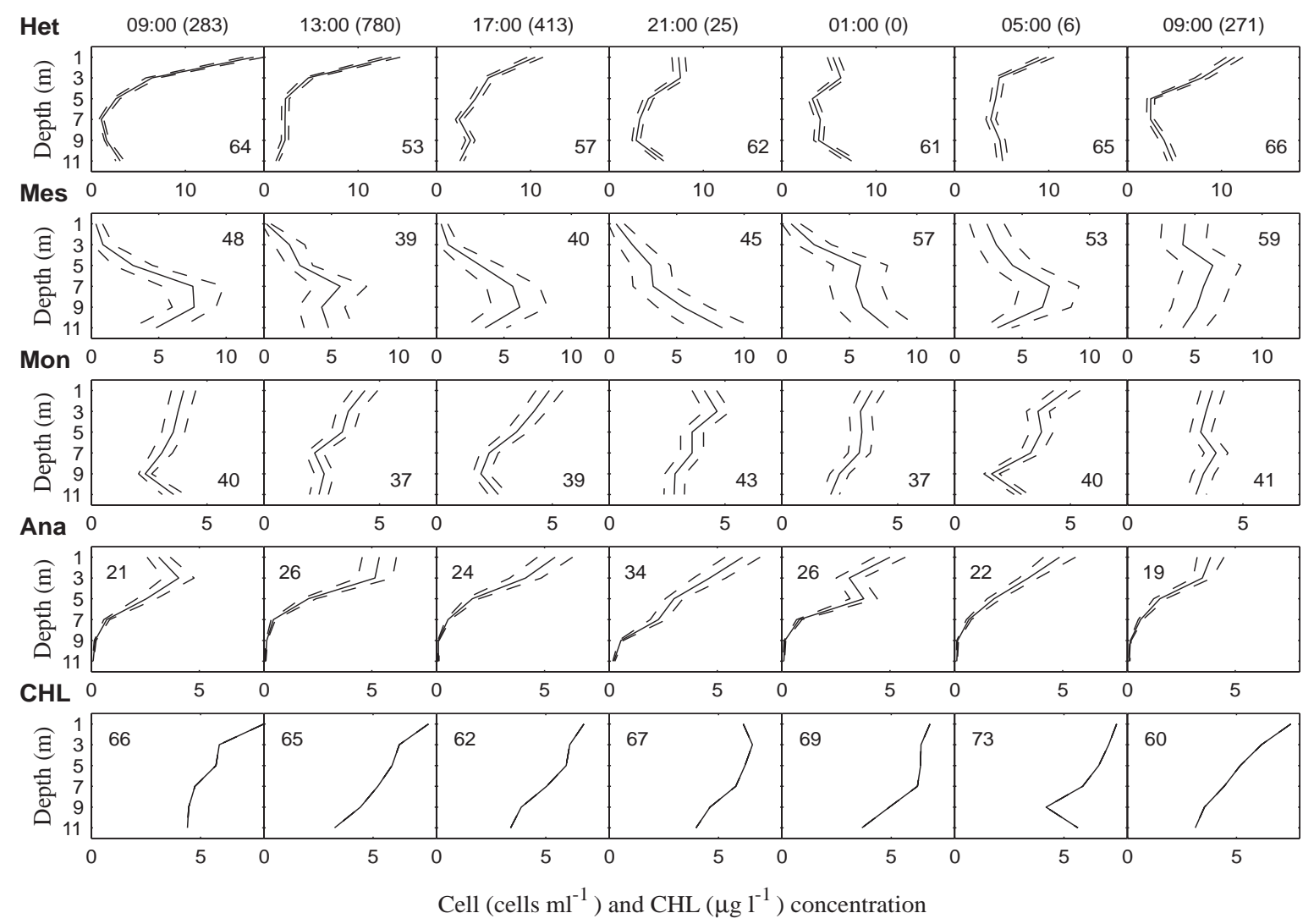

Fig. 2. Vertical abundance profiles of Heterocapsa triquetra (Het, $10^{2}$ cells ml ${ }^{-1}$ ), Mesodinium rubrum $\left(\mathrm{Mes}, 10^{1} \mathrm{cells} \mathrm{ml}^{-1}\right)$, Monoraphidium contortum (Mon, $10^{2}$ cells ml ${ }^{-1}$ ), Anabaena lemmermannii (Ana, $10^{2} 100 \mu \mathrm{m}$ filament length ml ${ }^{-1}$ ) and chlorophyll a $\left(\mathrm{CHL}, \mu \mathrm{g} \mathrm{l}^{-1}\right)$ in LN enclosure, 1996. Dashed lines: 95\% confidence intervals of the counts; numbers on top abscissa: sampling

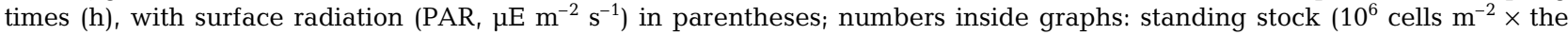
coefficient from respective cells $\mathrm{ml}^{-1}$ values) 

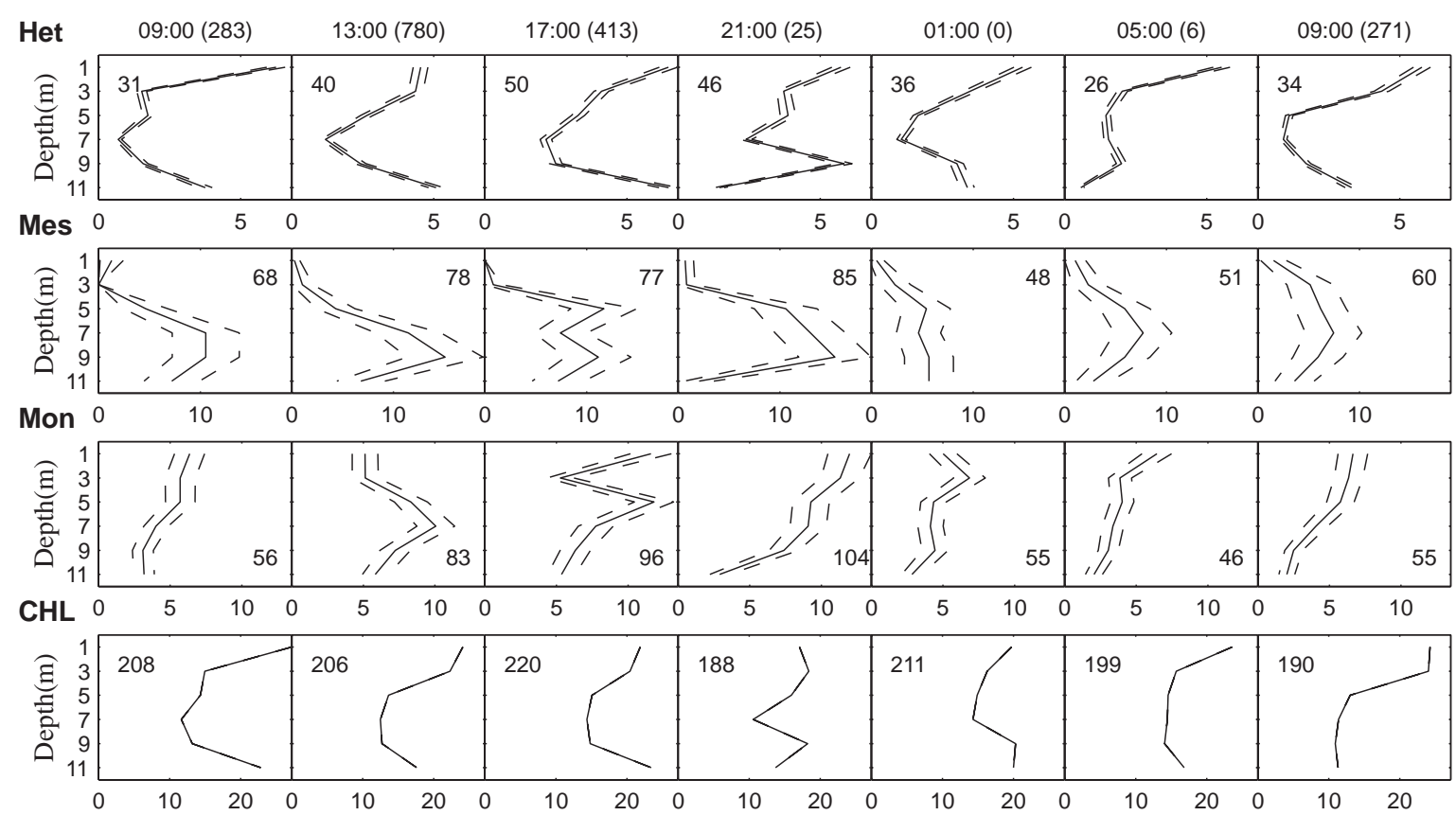

Cell (cells $\left.\mathrm{ml}^{-1}\right)$ and $\mathrm{CHL}\left(\mu \mathrm{g} \mathrm{l^{-1 }}\right)$ concentration

Fig. 3. Vertical abundance profiles of Heterocapsa triquetra (Het, $10^{3}$ cells ml ${ }^{-1}$ ), Mesodinium rubrum $\left(\mathrm{Mes}, 10^{1} \mathrm{cells} \mathrm{ml}^{-1}\right)$, Monoraphidium contortum (Mon, $10^{2}$ cells $\mathrm{ml}^{-1}$ ) and chlorophyll a (CHL, $\mu \mathrm{g} \mathrm{l}^{-1}$ ) in HN enclosure, 1996. Other details as in Fig. 2 legend

\section{8 experiment}

In both enclosures, Heterocapsa triquetra gradually increased in abundance towards the surface during daylight, with some aggregation in the deepest layer (Figs 4 \& 5). During the hours of darkness, the bulk of cells tended to inhabit the deeper layers. Aphanizomenon sp. displayed a quite variable depth distribution pattern, with strongest surface aggregation during daylight (Figs 4 \& 5). The Anabaena lemmermannii population stayed at the surface even during the dark period (Figs 4 \& 5). The vertical distribution of Mesodinium rubrum (Figs 4 \& 5) showed a similar deep aggregation and surface avoidance as in the 1996 experiment. The chl (Figs 4 \& 5) profiles agreed generally with the profiles of $H$. triquetra, as in 1996. In the LN enclosure, the chl profile also had a maximum at the surface during the dark period (Fig. 4), while a deep aggregation was also clearly evident. Again, this probably reflects the deep population of $H$. triquetra.

\section{Data analysis}

\section{Between-species effects}

Fig. 6 depicts the locations of vertical profiles on the first ordination planes. The individual profiles are grouped according to species and enclosures. For each group, the 7 profiles (corresponding to 7 sampling times) are connected to the group's center of gravity. Three effects are apparent from Fig. 6:

First, there is relatively little overlap between the profiles of different species. Most distinctive is the separate location of the profiles of Mesodinium rubrum on the right side of the ordination planes. According to the correlation of the 6 depths with the ordination axes (sub-plot in Fig. 6), this side of the ordination planes was largely defined by the deep layers (6 to $12 \mathrm{~m}$ ), consistent with the vertical distribution of $M$. rubrum (Figs 2 to 5). The profiles for the cyanobacteria are on the left side of the ordination planes in Fig. 6, relecting their relatively strong surface aggregation (Figs 2 to 5). It is interesting that although for 1998 the filamentous cyanobacteria groups (Aphanizomenon sp. and Anabaena lemmermannii) form clusters quite close to each other on the left side of the ordination plane, there is a clear difference between the species, indicating that they shared different vertical niches. For 1996, the profiles of Heterocapsa triquetra stand apart from those of Monoraphidium contortum and chl (Fig. 6). Note that for 1996, the group defined by chl in the HN enclosure (c2 in Fig. 6) is much closer to the profiles of $H$. triquetra. This probably reflects the high degree of dominance of $H$. triquetra in the HN enclosure and its strong effect on the chl profiles. For 1998, the profiles of $H$. triquetra overlap with the chl profiles. This 

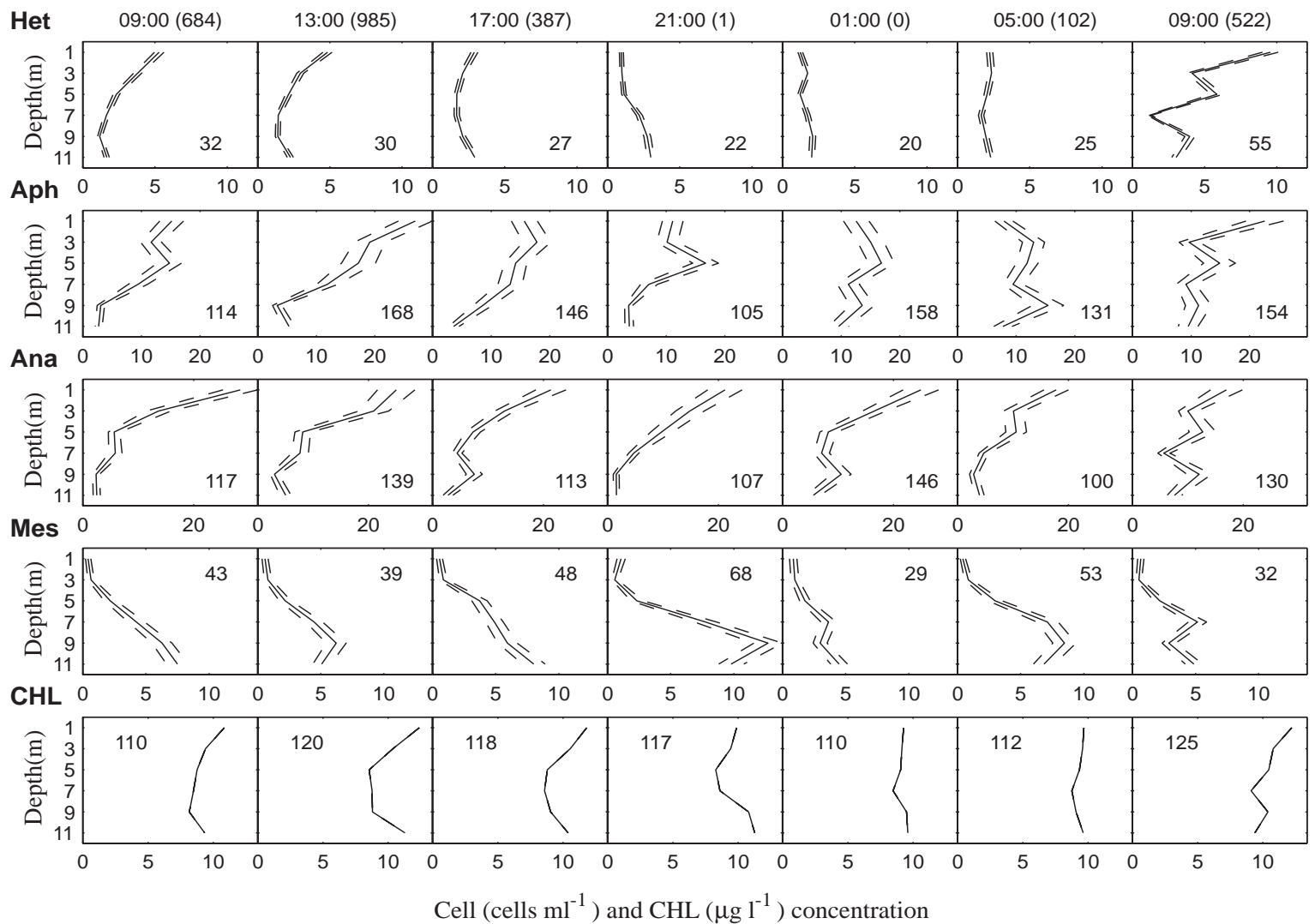

Fig. 4. Vertical abundance profiles of Heterocapsa triquetra (Het, $10^{2}$ cells ml ${ }^{-1}$ ), Aphanizomenon sp. (Aph, $10^{1} 100 \mu \mathrm{m}$ filament length $\mathrm{ml}^{-1}$ ), Anabaena lemmermannii (Ana, $10^{1} 100 \mu \mathrm{m}$ filament length $\mathrm{ml}^{-1}$ ), Mesodinium rubrum $\left(\mathrm{Mes}^{-1} 0^{1} \mathrm{cells}^{-1}\right.$ ), chlorophyll a (CHL, $\left.\mu \mathrm{g} \mathrm{l}^{-1}\right)$ in LN enclosure, 1998. Other details as in Fig. 2 legend

reflects the remarkable similarity in the shape of their respective vertical profiles (Figs 4 \& 5), and is explained by the dominance of $H$. triquetra in the phytoplankton assemblage.

Second, the profiles of the same species from different enclosures cluster quite closely. This indicates that the species tended to have a specific vertical distribution pattern quite independent of the nutrient loads.

Third, compared to Monoraphidium contortum and chl, the clusters of profiles of the motile species (particularly Mesodinium rubrum and Heterocapsa triquetra) have a much wider spread on the ordination plane. The spread of chl profiles in the HN enclosure for 1996 is relatively large, probably due to the strong influence of $H$. triquetra. This suggests that the shape of individual profiles of motile species varied much more during the course of a diel cycle, probably due to migratory behavior.

The spread of the groups along the ordination planes (Fig. 6) represents variation along the first 2 ordination axes. The overall extent of the variability in abundance of each species in both years and both nutrient load conditions (Fig. 7) gives a better representation of the relative degree of migratory activity. There was a decrease in migratory activity in the order Heterocapsa triquetra and Mesodinium rubrum to Aphanizomenon sp., Anabaena lemmermannii, Monoraphidium contortum and chl (Fig. 7). Interestingly, the migratory activity of $M$. rubrum was much lower in 1996 than in 1998.

The clear separation of the vertical profile groups, as defined by species, was statistically significant in both years ( 5 groups, $\mathrm{p}=0$ ). Since the experiments in both years were carried out during a similar successional stage of the plankton community (Niemi 1973, 1975) and the sampling schemes were identical in both experimental years, it was possible to combine the 2 data sets and include the inter-annual variance in an analysis of vertical profiles. Randomization tests revealed that the groups defined by species only (6 groups) or species and years (10 groups) were significantly different $(p=0)$. This was also the case when chl, as a combined parameter for the whole phytoplankton community, was excluded from the analysis. Fig. 8A shows the first ordination plane with the positions of vertical profiles grouped according to species 

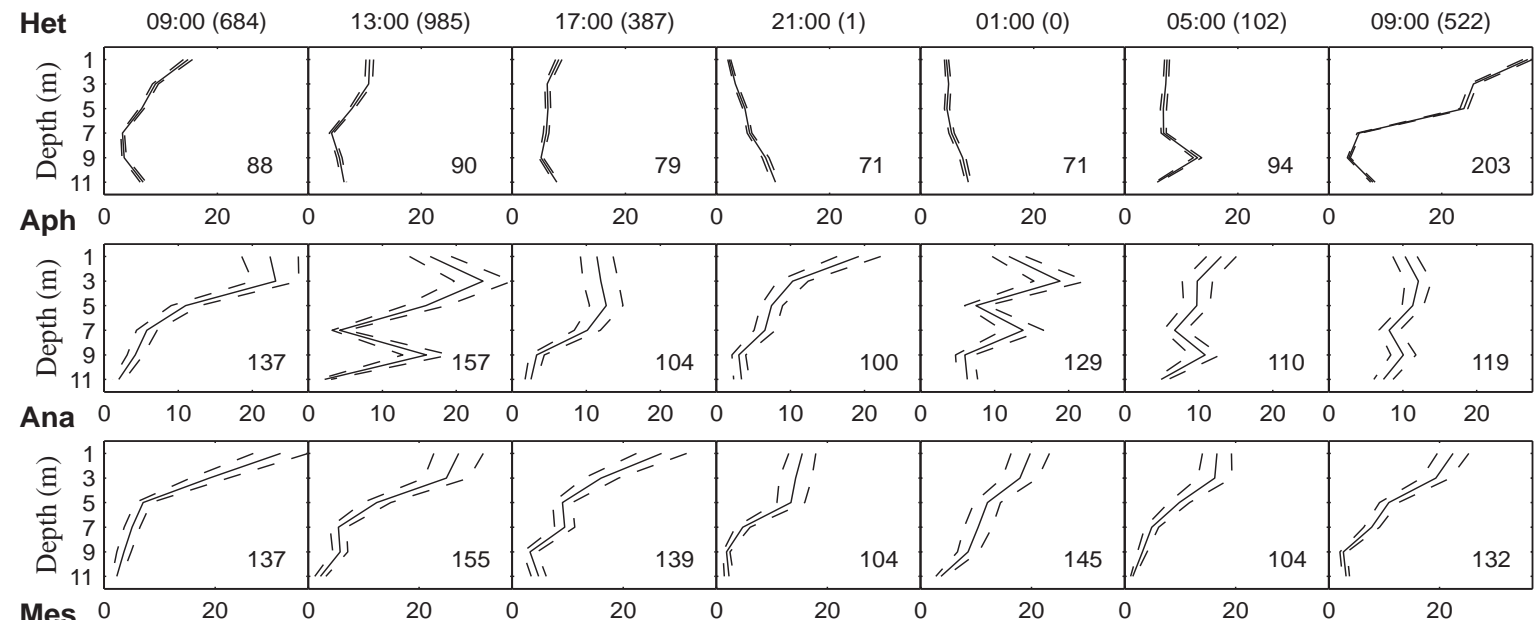

Mes 0

$\begin{array}{lllllllllllllll}\text { CHL } & 0 & 20 & 400 & 20 & 400 & 20 & 400 & 20 & 400 & 20 & 400 & 20 & 400 & 20\end{array}$

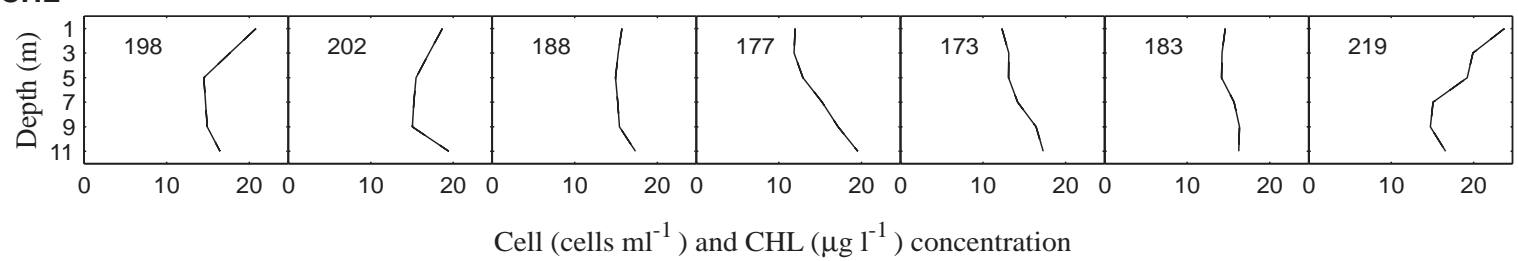

Fig. 5. Vertical abundance profiles of Heterocapsa triquetra (Het, $10^{2}$ cells ml ${ }^{-1}$ ), Aphanizomenon sp. (Aph, $10^{1} 100 \mu \mathrm{m}$ filament length $\mathrm{ml}^{-1}$ ), Anabaena lemmermannii (Ana, $10^{1} 100 \mu \mathrm{m}$ filament length ml ${ }^{-1}$ ), Mesodinium rubrum $\left(\mathrm{Mes}^{1}, 10^{1} \mathrm{cells} \mathrm{ml^{-1 }}\right.$ ), chlorophyll a (CHL, $\left.\mathrm{gg} \mathrm{l}^{-1}\right)$ in HN enclosure, 1998. Other details as in Fig. 2 legend
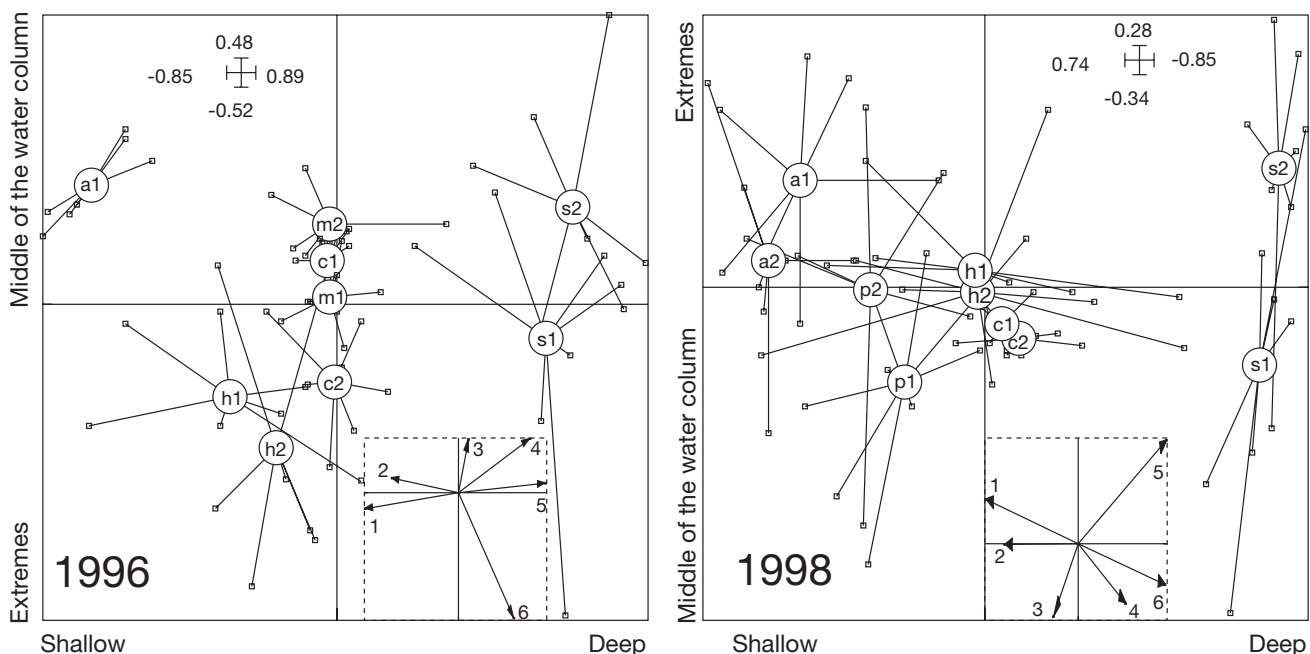

Fig. 6. Vertical distributions of Heterocapsa triquetra (h), Mesodinium rubrum (s), Monoraphidium contortum (m), Anabaena lemmermannii (a), Aphanizomenon sp. (p) and chlorophyll a (c) projected onto 2-dimensional planes. Numbers after letters denote nutrient loads: 1 = low and 2 = high nutrient load. Groups, defined by nutrient load and species, are connected to their respective centers of gravity. Ordination axes ( $x$ first and $y$ second) are defined to maximize the variance between all data points. Axes are labeled with their intuitive interpretation. Small sub-plots surrounded by dashed line represent the correlation of the

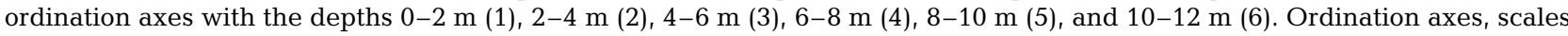
are shown on the upper parts of the panels 


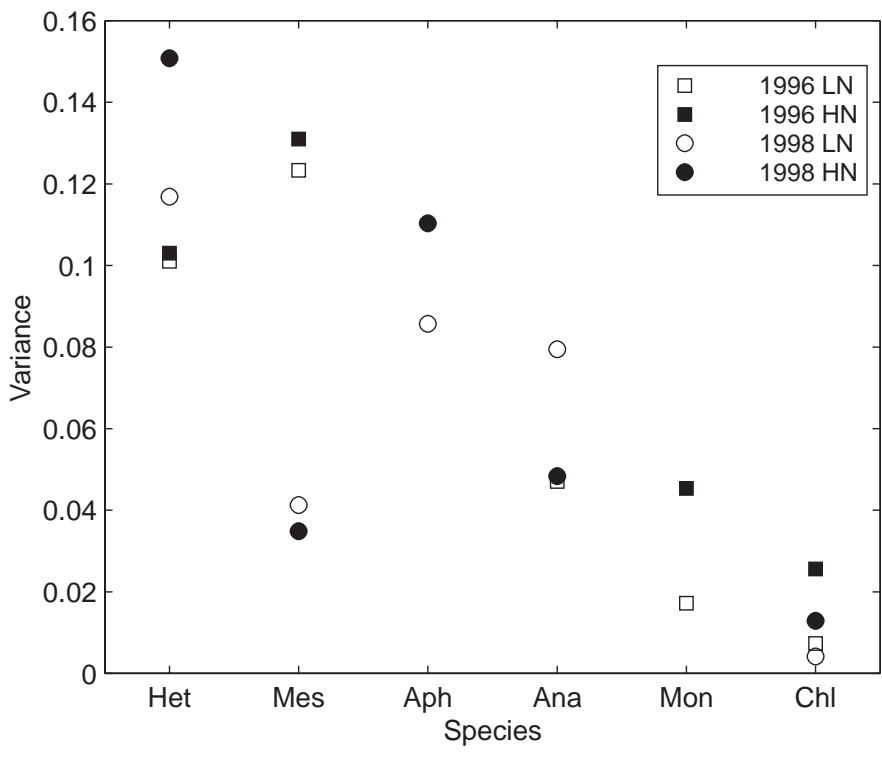

Fig. 7. Variance of the vertical profiles of species within the 4 mesocosms. Het: Heterocapsa triquetra; Mes: Mesodinium rubrum; Aph: Aphanizomenon sp.; Ana: Anabaena lemmermannii; Mon: Monoraphidium contortum; Chl: chlorophyll a. Note decrease in variability from motile species towards Mon and $\mathrm{Chl}$

(chl excluded for clarity) and years. The separate location of Mesodinium rubrum on the right side of the ordination plane, which corresponds to the deeper layers (see sub-panel in Fig. 8A), is apparent. However, the distribution of $M$. rubrum during both years was clearly different. The profiles of filamentous cyanobacteria all cluster relatively close to the upper left part of the ordination plane in Fig. 8A, which was more influenced by the surface layers (sub-panel in Fig. 8A).

\section{Within-species effects}

The conclusion that, when generalized over the 2 experimental years and different nutrient loads, the abundance profiles are species-specific does not automatically mean that the nutrient load and inter-annual variance were insignificant in determining the shape of the vertical distribution patterns of individual species. Below, we consider separately the data sets of 2 individual species and examine the effects of nutrient load and inter-annual variability. For 2 species (Heterocapsa triquetra and Mesodinium rubrum) and chl, four $24 \mathrm{~h}$ data sets from both experimental years and from enclosures with 2 different nutrient loads are available.

\section{Heterocapsa triquetra}

There was considerable overlap between the vertical profiles for Heterocapsa triquetra grouped according to year and enclosure (4 groups), and a randomization test revealed no significant difference $(p=0.1238$; see also Table 4). However, the inter-annual variance was significant $(p=0.0145)$, whereas differences in nutrient
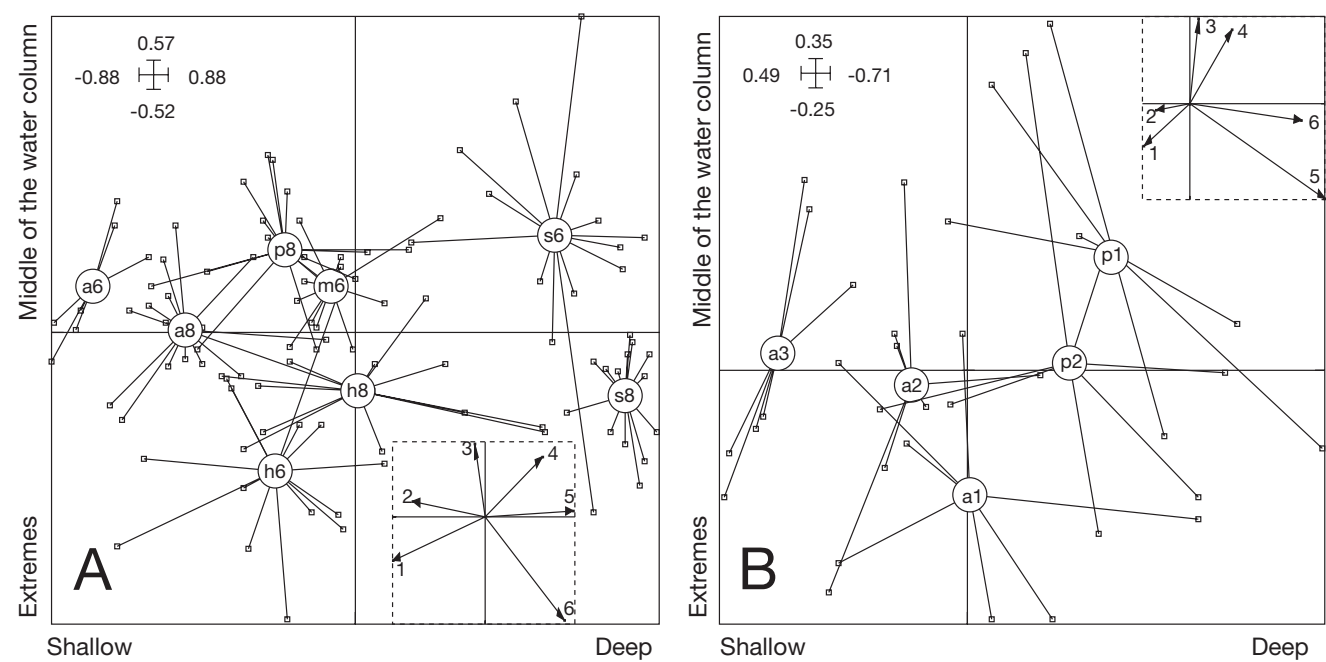

Fig. 8. (A) Vertical distributions of species (letters, denoted as in Fig. 6) projected onto first ordination plane. Numbers after letters denote experimental year: $6=1996$ and $8=1998$. Grouping is based on species and year as the effect of nutrient load was never significant while the effect of year was significant in all cases. Chlorophyll a has been excluded for clarity. (B) Vertical distributions of cyanobacteria projected onto first ordination plane. p: Aphanizomenon sp. $(1=1998$ LN; $2=1998$ HN); a: Anabaena lemmermannii $(1=1998 \mathrm{LN} ; 2=1998 \mathrm{HN} ; 3=1996 \mathrm{LN})$. Labels of ordination axes, correlation of ordination axes with depths, and ordination axes scales as in Fig. 6 
load had no significant effect $(p=0.6836)$. The effect of nutrient load was also not significant when data from the years $1996(p=0.4308)$ or $1998(p=0.9575)$ were considered separately.

A significant difference was found when the vertical profiles were grouped according to sampling time ( 7 groups, $p=0.0101$ ). This means that the change in the shape of the vertical profiles of Heterocapsa triquetra was synchronized over time (cf. Figs 2 to 5). To reveal the effect of the diel cycle, a within-groups correspondence analysis was performed. This analysis removes the effect of different enclosures (i.e., both interannual variability and variability due to nutrient manipulations) and the vertical profiles are scattered with maximal variance around the axis origin (Fig. 9). Fig. 9 shows the temporal typologies of the vertical profiles in the 4 enclosures. The first ordination axis correlates well with the depth gradient, while the second axis is strongly influenced by the 2 deeper layers in opposite directions (sub-panel in Fig. 9). In all but the HN enclosure in the 1996 experiment, the vertical profiles reveal a diel movement from the right side of the plane (corresponding to surface layers and light interval) to the left side (deep layers, dark interval) and back again by the next morning. In the $1996 \mathrm{HN}$ enclosure, the deep aggregation of $H$. triquetra at 21:00 h occurred at 8 to $10 \mathrm{~m}$ (Fig. 3), which differed from the usual 10 to $12 \mathrm{~m}$ peak (Figs $2 \& 3$ ). This resulted in a deflection of the shape of the vertical profile to an extent that betweengroup differences (grouped according to sampling time) were not significant $(p=0.5388)$ in 1996. However, the effect of time on the distribution patterns of $H$. triquetra in 1998 was highly significant $(\mathrm{p}=0.0001)$.

\section{Mesodinium rubrum}

Mesodinium rubrum had a significantly different vertical distribution $(p=0.0006)$ when all 4 enclosures were considered separately; most of this difference was due to the significant inter-annual variance $(p=0)$. Diel cycle had no significant effect whether the 2 years were combined $(p=0.1725)$ or considered separately (Table 4). The effect of nutrient load was not significant when both years were combined ( $p=0.1251)$ or in 1996 alone $(p=0.2414)$, but in 1998 the nutrient load effect was quite close to being significant $(p=0.05478$; $10 \mathrm{E}+5$ permutations).

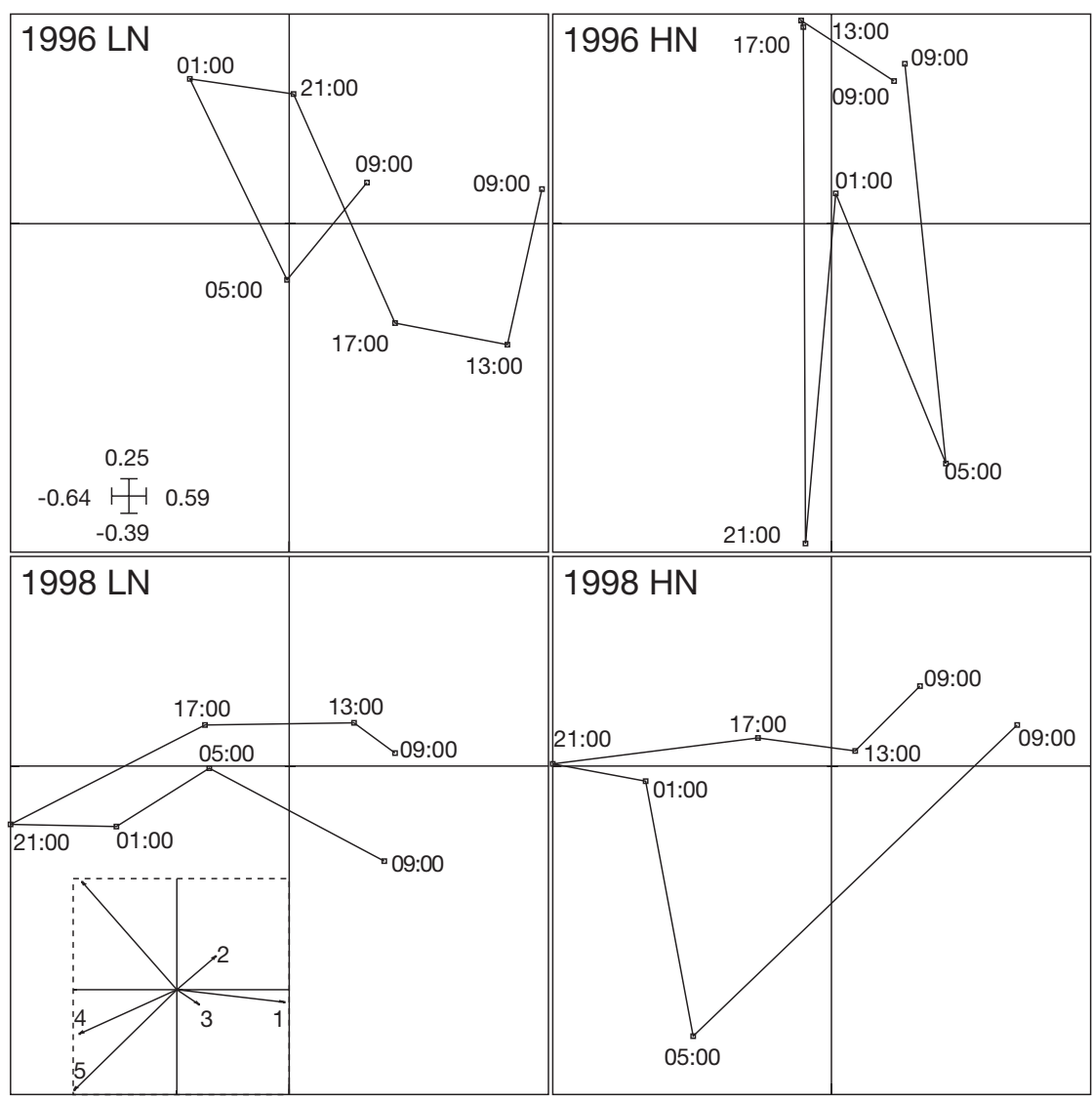

Shallow
Fig. 9. Heterocapsa triquetra. Temporal typologies of vertical profiles in the 4 enclosures. Correlation of ordination axes with depths, labels of $x$ axis, and ordination axes scales are the same for all graphs. Sampling times $(\mathrm{h})$ are shown on depth profiles 
Table 4. Significance (p) of between-group analysis revealed by randomization tests with $10^{4}$ or $10^{5}\left(^{*}\right)$ simulations on subsets of the data. (Het: Heterocapsa triquetra; Mes: Mesodinium rubrum; Ana: Anabaena lemmermannii; Aph: Aphanizomenos sp.; Cya: Ana + Aph; 1996, 1998 denote cases when the test was restricted to a particular year). Effect: single or combined effect of nutrient load (nutr), year, sampling time (time) or species (sp); Groups: number of groups; Profiles: number of individual profiles included in the particular test. Only within-species analyses are shown, since the differences between species within a particular year or when data from both years were pooled resulted always in $p=0$

\begin{tabular}{|c|c|c|c|c|}
\hline Sub-set & Effect & Groups & Profiles & $\mathrm{p}$ \\
\hline Het & Nutr $\times$ Year & 4 & 28 & 0.1238 \\
\hline Het & Time & 7 & 28 & 0.0101 \\
\hline Het & Year & 2 & 28 & 0.0145 \\
\hline Het & Nutr & 2 & 28 & 0.6836 \\
\hline Het 1996 & Nutr & 2 & 14 & 0.4308 \\
\hline Het 1996 & Time & 7 & 14 & 0.5388 \\
\hline Het 1998 & Nutr & 2 & 14 & 0.9575 \\
\hline Het 1998 & Time & 7 & 14 & 0.0001 \\
\hline Mes & Nutr $\times$ Year & 4 & 28 & 0.0006 \\
\hline Mes & Time & 7 & 28 & 0.1725 \\
\hline Mes & Year & 2 & 28 & 0 \\
\hline Mes & Nutr & 2 & 28 & 0.1251 \\
\hline Mes 1996 & Nutr & 2 & 14 & 0.2414 \\
\hline Mes 1996 & Time & 7 & 14 & $0.08786^{*}$ \\
\hline Mes 1998 & Nutr & 2 & 14 & $0.05478^{*}$ \\
\hline Mes 1998 & Time & 7 & 14 & 0.4529 \\
\hline Cya & $\begin{array}{l}\text { Species } \times \text { Nutr } \\
\times \text { Year }\end{array}$ & 5 & 30 & 0 \\
\hline Сyа & Time & 7 & 30 & 0.1013 \\
\hline Сya & Species & 2 & 30 & 0.0001 \\
\hline Суа 1998 & Species & 2 & 28 & 0.0007 \\
\hline Сyа 1998 & Species $\times$ Nutr & 4 & 28 & 0.0038 \\
\hline Суа 1998 & Time & 7 & 28 & 0.0969 \\
\hline Суа 1998 & Nutr & 2 & 28 & 0.3153 \\
\hline$A p h$ & Nutr & 2 & 14 & 0.4545 \\
\hline Aph & Time & 7 & 14 & 0.1329 \\
\hline Ana & Nutr $\times$ Year & 3 & 21 & 0 \\
\hline Ana & Time & 7 & 21 & 0.9113 \\
\hline Ana 1998 & Nutr & 2 & 14 & 0.2023 \\
\hline Ana 1998 & Time & 7 & 14 & 0.2119 \\
\hline
\end{tabular}

\section{Filamentous cyanobacteria}

Fig. 8A shows that the cyanobacterial groups tended to separate from the other phytoplankton groups. Within the cyanobacteria (Fig. 8B), the 2 species Anabaena lemmermannii and Aphanizpmenon sp. had significantly different vertical distribution patterns when the data from both years were considered $(\mathrm{p}=$ 0.0001) and when the data from 1998 were analyzed separately ( $p=0.0007)$. A randomization test revealed no significant effect of the nutrient load on the vertical distribution when all the data from 1998 were analyzed $(\mathrm{p}=0.3153)$, or when both species were analyzed separately (A. lemmermannii, $\mathrm{p}=0.2023$; Aphanizomenon sp., $\mathrm{p}=0.4545)$. A significant inter-annual effect $(\mathrm{p}=$ $0.0003)$ was revealed for A. lemmermannii. In no case did the vertical profiles differ significantly when grouped according to sampling time (Table 4).

\section{DISCUSSION}

The present study showed significant species-specific differences in the vertical distribution patterns of autotrophic micro-organisms in large-scale mesocosms which covered a light gradient down to $<1 \%$ of surface irradiance. A highly significant inter-annual variability in vertical distribution was evident for each individual species studied. However, species-specific differences were clearly more pronounced than inter-annual variability or that caused by nutrient supply rates. These results demonstrate the vertical segregation of autotrophic micro-organisms in the water column. Vertical segregation of phytoplankton species has been documented before (Ganf \& Oliver 1982, Sommer 1982, 1985). However, here we have demonstrated in a formal, testable way that patterns of segregation are species-specific and robust, and are not overly sensitive to changes in environmental conditions.

A particular strategy of vertical niche separation is motility. Differences in short-term ( $24 \mathrm{~h}$ ) variability in the shape of vertical distribution profiles separated the species along a motility gradient. This was exemplified by the characteristic wide scatter of the vertical profile groups of motile species on an ordination plane compared to those of non-motile species (Fig. 7), indicating that motile species can exploit resources from a wider depth range in the water column. Vertical movements were apparent as clearly recognizable DVM (diurnal surface and nocturnal deep aggregations), as in the cases of Heterocapsa triquetra, but were not limited to DVM, as in the cases of Mesodinium rubrum and Aphanizomenon sp. The vertical separation of some species, e.g. M. rubrum, was so evident that it did not call for a formal statistical test. However, in most cases visual examination of raw profiles (Figs 2 to 5) or even representation on an ordination plane were not conclusive. Our results convincingly demonstrate a vertical separation of 2 species of filamentous cyanobacteria (Anabaena lemmermannii and Aphanizomenon sp.) that may occupy close vertical niches.

The lack of a clear nutrient manipulations effect deserves some attention. In both years there was a notable accumulation of ammonium during the first week. Thereafter the phytoplankton community was well adapted to the new nutrient regimes and efficiently assimilated the added ammonium during a $24 \mathrm{~h}$ 
period. It is likely that the apparent nutrient regimes in the LN and HN enclosures were more similar than what would be expected from the large differences in the absolute nutrient loads (2.5 and 4.9 times in 1998 and 1996, respectively). At the time of the vertical profile sampling the chl-normalized ammonium load of the HN enclosure exceeded that of LN enclosure by a factor of only 1.52 (1998) or 1.59 (1996). Although this is smaller than the differences between the absolute loads, it still suggests a considerable contrast in the apparent nutrient regimes experienced by the algae. Community-level nutrient limitation in the HN enclosures cannot be excluded, since enclosures with even higher nutrient loads also supported higher chl concentrations (data not shown).

Heterocapsa triquetra showed the clearest DVM behavior, as seen in the raw vertical profile plots (Figs 2 to 5) and the ordination plane (Fig. 9). The consistency of this behavior over both years and nutrient loads was confirmed by a formal statistical test. In 1996, H. triquetra was already abundant in the initial phase of the experiment and increased after the nutrient additions. Interestingly, in 1998 only trace concentrations of $H$. triquetra were present in the initial water columm, but this species became dominant during the latter part of the experiment. Possibly part of this success could be attributed to DVM behavior.

The vertical distribution of Mesodinium rubrum was consistent with that recorded in earlier studies in the coastal Baltic Sea (Olli et al. 1998, Olli 1999). All the data indicate that during summer $M$. rubrum is relatively uniformly distributed in the upper mixed layer, or inhabits the deeper parts of the mixed layer just above the pycnocline, in contrast to its very dense and shallow surface aggregation during the vernal bloom (Olli et al. 1998, Olli 1999). These data suggest that in the Baltic Sea M. rubrum favors relatively lower temperatures and/or high nutrient concentrations.

Much of the variability in the light conditions within the mesocosms arose from environmental light attenuation, and not from variability in phytoplankton biomass caused by different nutrient supply rates. Supposing the chl-specific vertical attenuation coefficient of PAR for phytoplankton to have a range of 0.005 to $0.03 \mathrm{~m}^{2} \mathrm{mg}^{-1} \mathrm{chl} a$, the light attenuation due to algae can be calculated as a product of chl concentration and this coefficient (Kirk 1994). The 0 to $12 \mathrm{~m}$ depth integrated concentration of chl varied from 2.5 to $22 \mu \mathrm{g} \mathrm{chl}$ $\mathrm{l}^{-1}$, which, using a chl-specific vertical attenuation coef-

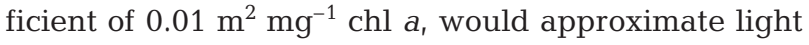
attenuation of 0.03 to $0.22 \mathrm{~m}^{-1}$. However, the lack of correlation between chl concentration and light attenuation in the mesocosms suggests that much of the light came from the surrounding water column through the plastic walls of the mesocosms, not from above, and was controlled by the turbidity of the water masses passing the experimental site. This is very plausible given the large depth-to-diameter ratio (6.1) of the enclosures and the relatively high ratio of scattering to absorbtion in determining the light attenuation in Baltic coastal waters (Seppälä unpubl. data), and suggests that within a given year the light conditions within the LN and HN enclosures were much more similar than what could be expected from open-water phytoplankton blooms of equivalent densities.

The vertical segregation of phytoplankton populations can potentially have important consequences for inter-specific interactions, especially competition and co-existence. Migration and vertical niche separation can counteract inter-specific resource competition of planktonic micro-organisms (Angeli et al. 1995). Based on differences in their nutrient and light preferences, phytoplankton species can inhabit and exploit different vertical niches in the water column (Ganf \& Oliver 1982, Makulla \& Sommer 1993). Several studies have analyzed light:nutrient ratios in the perspective of phytoplankton resource competition (Sommer 1988b, 1993, 1994). Could the intrinsic nature of the light gradient in aquatic habitats cause vertical heterogeneity and provide a solution to Hutchinson's (1961) challenge that the high diversity of species present in plankton is inconsistent with the assumption of competitive exclusion in the supposed uniformity of pelagic environments (known as 'the paradox of the plankton')?

Huisman \& Weissing $(1994,1995)$ developed a phytoplankton light competition model, which predicts that competition for light and nutrients is inherently different from competition for 2 or more nutrients. In a wellmixed volume of water it is not only the ratio of nutrient supply to light supply that determines the outcome of species competition, but also the absolute supply rates of light (Huisman \& Weissing 1994, Weissing \& Huisman 1994, Huisman 1999, Huisman et al. 1999). In a well-mixed water column with a uniform distribution of competitors, the absolute supply rate of light to the cells is equal, and consequently the vertical light gradient does not provide spatially heterogeneous conditions for phytoplankton growth (Huisman \& Weissing 1994, Weissing \& Huisman 1994). The theory of competition for light in a well-mixed habitat preserves the classical limit to species diversity - the number of resources for which competition occurs (Huisman \& Weissing 1995), and the vertical light gradient is not sufficient to solve Hutchinson's paradox of the plankton.

The phytoplankton light-competition model depends crucially on the uniform distribution of competitors, which is usually achieved by an externally imposed mixing of the water column (Huisman \& Weissing 
1994, Weissing \& Huisman 1994). When this requirement is not fulfilled, as in the case of motile organisms and/or incomplete mixing, phytoplankton species become spatially differentiated, and equilibrium co-existence of several species competing for even a single resource is likely to occur (Weissing \& Huisman 1994).

As shown in the present study, the autotrophic species consistently inhabit different parts of the water column, probably supported by incomplete mixing and/or motility of the organisms. It should be stressed that this vertical segregation is not limited to differences in the depths of the populations' distribution maxima, but is a dynamic phenomenon, whereby an important component is variability in the distribution profiles over a diel cycle. The vertical distribution patterns of individual species could be fairly dynamic during a diel cycle, but at the same time recognizably similar over an inter-annual scale, and with variable nutrient supply rates. Consequently, the populations experience differences in both the absolute supply rates and the ratios of potentially limiting recources. Theoretically, this condition is sufficient for stable coexistence of several species competing for a limited number of resources. Strictly, it does not solve Hutchinson's paradox of the plankton which assumes homogeneity of the water column. Rather it shows that the water column is not homogeneous, at least with respect to vertical distribution of the organisms, i.e. the micro-organisms do not regard the environment as homogeneous.

Indeed, the actual vertical distribution of species in a natural water column arises from a combination of physical mixing and motility as the organisms seek an optimal compromise between light- and nutrient-limitation. Phytoplankton which sink, float or maintain their swimming movements are liable to be re-distributed throughout the depth of the turbulent layer. The extent to which they are redispersed within it depends upon the magnitude of the ratio between the average vertical turbulent velocity fluctuation and the vertical velocity of the cell movement (Reynolds 1997). Humphries \& Imberger (cited in Reynolds 1997) showed that a ratio of about 15 was required to maintain mixed-layer populations in approximately uniform suspension. Clearly, in natural systems, turbulent velocity is extremely variable in time and space, depending on the energy of the mechanical forcing and the speed of its dissipation through the eddy spectrum. In the simplest model of open water of infinite depth and horizontal expanse and lacking any density stratification and subject to wind stress of constant velocity and direction, a sufficiently robust estimate of turbulent velocity can be calculated from windspeed in the range of 5 to $20 \mathrm{~m} \mathrm{~s}^{-1}$ by multiplying with a coefficient of $1.25 \times 10^{-3}$ (Reynolds 1997). Taking $10^{-3} \mathrm{~m} \mathrm{~s}^{-1}$ as the speed of movement of a large flagellate or buoyant cyanobacterium, a wind speed as high as $12 \mathrm{~m} \mathrm{~s}^{-1}$ would be needed for turbulent diffusion to dominate the motile particle distribution. Although such wind speed is not unnatural, the usual wind speeds in the coastal Baltic are lower. However, most of the deep (>10 m depth) basins of the temperate-cold zone are stratified during the productive period of spring to late autumn (Sorokin 1999); this counteracts wind-forced mixing. After a deep mixing has occurred, only $1 \mathrm{~d}$ is necessary to restore thermal stratification in summer (Olli 1999). Studies from the open coastal waters also revealed a consistent vertical segregation of phytoplankton populations (Olli et al. 1998, Olli 1999), and support the conclusions of this study that vertical segregation is a robust, species-specific property.

In summary, the experimental data suggest that the patterns of vertical segregation of phytoplankton in the water column are species-specific and robust. They appear to be persistent biological phenomena, not overly sensitive to changing environmental conditions or accidents of hydrodynamics or sampling procedures. The vertical niche separation of phototrophic micro-organisms is expressed as (1) systematic differences between the vertical distribution of individual species along the depth gradient, and (2) interspecific differences in migratory activity. The latter can be in the form of recognizable DVM or high variability in the shape of vertical abundance profiles with no clear links to diel rhythm. These conclusions have potential implications for species competition, co-existence, and diversity.

Acknowledgements. This study was supported by the Estonian Science Foundation (ETF 3329), the Walter and Andreé de Nottbeck Foundation, Fulbright Foundation, and NSF/NATO Grant DGE-9804544 (K.O.). We are grateful to the research team PELAG (T. Tamminen, A. S. Heiskanen, R. Lignell, K. Kivi, P. Tuomi, and P. Kuuppo) for planning and executing the mesocosm experiments. We thank the staff of the Tvärminne Zoological Station (University of Helsinki) for their help and hospitality, particularly M. Sjöblom and E. Leskinen for nutrient analysis. Comments of D. M. Anderson's laboratory members (WHOI) and 4 anonymous referees improved the manuscript. The mesocosm experiment was part of a MAST III project COMWEB (No.: CT960052) and is Contribution No. 10343 from the Woods Hole Oceanographic Institution.

\section{LITERATURE CITED}

Angeli N, Pinel-Alloul B, Balvay G, Menard I (1995) Diel patterns of feeding and vertical migration in daphnids and diaptomids during the clear water phase in Lake Geneva (France). Hydrobiologia 300-301:163-184

Blasco D (1978) Observations on the diel migration of marine dinoflagellates off the Baja California coast. Mar Biol 46 $41-47$

Cullen JJ (1985) Diel vertical migration by dinoflagellates: roles of carbohydrate metabolism and behavioural flexi- 
bility. In: Rankin MA, Checkley D, Cullen J, Kitting C, Thomas P (eds) Migration: mechanisms and adaptive significance. Marine Science Institute, The University of Texas at Austin, p 135-152

Eppley RW, Holm-Hansen O, Strickland JDH (1968) Some observations on the vertical migration of dinoflagellates. J Phycol 4:333-340

Ganf GG, Oliver RL (1982) Vertical separation of light and available nutrients as a factor causing replacement of green algae by blue-green algae in the plankton of a stratified lake. J Ecol 70:829-844

Gasol JM, García-Cantizano J, Massana R, Guerrero R, Pedrós-Alió C (1993) Physiological ecology of a metalimnic Cryptomonas population: relationship to light, sulphide and nutrients. J Plankton Res 15:255-257

Grasshoff K, Ehrhardt M, Kremling K (1983) Methods of seawater analysis. Verlag Chemie, Weinheim

Haapala J (1994) Upwelling and its influence on nutrient concentration in the coastal area of the Hanko peninsula, entrance of the Gulf of Finland. Estuar Coast Shelf Sci 38: $507-521$

Heaney SI, Butterwick C (1985) Comparative mechanisms of algal movement in relation to phytoplankton production. In: Rankin MA, Checkley D, Cullen J, Kitting C, Thomas P (eds) Migration: mechanisms and adaptive significance. Marine Science Institute, The University of Texas at Austin, p 115-134

Heaney SI, Eppley RW (1981) Light, temperature and nitrogen as interacting factors affecting diel vertical migration of dinoflagellates in culture. J Plankton Res 3:331-344

Huisman J (1999) Population dynamics of light-limited phytoplankton: microcosm experiments. Ecology 80:202-210

Huisman J, Weissing FJ (1994) Light-limited growth and competition for light in well-mixed aquatic environments: an elementary model. Ecology 75:507-520

Huisman J, Weissing FJ (1995) Competition for nutrients and light in a mixed water column: a theoretical analysis. Am Nat 146:536-564

Huisman J, Jonker RR, Zonneveld C, Weissing FJ (1999) Competition for light between phytoplankton species: experimental test of mechanistic theory. Ecology 80:211-222

Hutchinson GE (1961) The paradox of the plankton. Am Nat 95:137-145

Jones RI (1991) Advantages of diurnal vertical migration to phytoplankton in sharply stratified, humic forest lake. Arch Hydrobiol 120:257-266

Kamykowski D (1995) Trajectories of autotrophic marine dinoflagellates. J Phycol 31:200-208

Kamykowski D, McCollum A (1986) The temperature acclimatized swimming speed of selected marine dinoflagellates. J Plankton Res 8:275-287

Kirk JTO (1994) Light and photosynthesis in aquatic ecosystems. Cambridge University Press, Cambridge

Klemer AR (1985) Nutrient-induced migration of blue-green algae (Cyanobacteria). In: Rankin MA, Checkley D, Cullen J, Kitting C, Thomas P (eds) Migration: mechanisms and adaptive significance. Marine Science Institute, The University of Texas at Austin, p 153-165

Klemer AR, Feuillade J, Feuillade M (1982) Cyanobacterial blooms: carbon and nitrogen limitation have opposite effects on the buoyancy of Oscillatoria. Science 215:1629-1631

Lindholm T (1981) On the ecology of Mesodinium rubrum (Lohmann) (Ciliata) in a stagnant brackish basin on Åland, SW Finland. Kiel Meeresforsch (Sonderh) 5:117-123

Lindholm T (1992) Ecological role of depth maxima of phytoplankton. Arch Hydrobiol Beih Ergebn Limnol 35:33-45
Makulla A, Sommer U (1993) Relationships between resource ratios and phytoplankton species composition during spring in five north German lakes. Limnol Oceanogr 38: 846-856

Niemi Å (1973) Ecology of phytoplankton in the Tvärminne area, SW coast of Finland. I. Dynamics of hydrography, nutrients, chlorophyll $a$ and phytoplankton. Acta Bot Fenn 100:1-68

Niemi $\AA$ (1975) Ecology of phytoplankton in the Tvärminne area, SW coast of Finland. II. Primary production and environmental conditions in the archipelago and the sea zone. Acta Bot Fenn 105:1-73

Oliver RL (1994) Floating and sinking in gas-vacuolated cyanobacteria. J Phycol 30:161-173

Olli K (1999) Diel vertical migration of phytoplankton and heterotrophic flagellates in the Gulf of Riga. J Mar Syst 23: 145-163

Olli K, Heiskanen AS, Seppälä J (1996) Development and fate of Eutreptialla gymnastica bloom in nutrient enriched enclosures in the coastal Baltic Sea. J Plankton Res 18: $1587-1604$

Olli K, Heiskanen AS, Lohikari K (1998) Vertical migration of autotrophic micro-organisms during a vernal bloom at the coastal Baltic Sea-coexistence through niche separation. Hydrobiologia 363:179-189

Reynolds CS (1997) Vegetation processes in the pelagic: a model for ecosystem theory. In: Kinne O (ed) Excellence in ecology. Ecology Institute, Oldendorf/Luhe

Sommer U (1982) Vertical niche separation between two closely related planktonic flagellate species (Rhodomonas lens and Rhodomonas minuta v. nannoplanctica ). J Plankton Res 4:137-142

Sommer U (1985) Differential migration of Cryptophyceae in lake Constance. In: Rankin MA, Checkley D, Cullen J, Kitting $\mathrm{C}$, Thomas $\mathrm{P}$ (eds) Migration: mechanisms and adaptive significance. Marine Science Institute, The University of Texas at Austin, p 166-175

Sommer U (1988a) Some size relationships in phytoflagellate motility. Hydrobiologia 161:125-131

Sommer U (1988b) The species composition of Antarctic phytoplankton interpreted in terms of Tilman's competition theory. Oecologia 77:464-467

Sommer U (1993) Phytoplankton competition in Plußsee: a field test of the resource-ratio hypothesis. Limnol Oceanogr 38:838-845

Sommer U (1994) The impact of light intensity and daylength on silicate and nitrate competition among marine phytoplankton. Limnol Oceanogr 39:1680-1688

Sorokin YI (1999) Aquatic microbial ecology. Backhuys Publishers, Leiden

Staker RD, Bruno HH (1980) Diurnal vertical migration in marine phytoplankton. Bot Mar 23:167-172

Throndsen J (1973) Motility in some marine nanoplankton flagellates. Norw J Zool 21:193-200

Villareal TA, Carpenter EJ (1990) Diel buoyancy regulation in the marine diazotrophic cyanobacterium Trichodesmium thiebautii. Limnol Oceanogr 35:1832-1837

Weissing FJ, Huisman J (1994) Growth and competition in a light gradient. J Theor Biol 168:323-336

West NJ, Scanlan DJ (1999) Niche-partitioning of Prochlorococcus populations in a stratified water column in the eastern North Atlantic Ocean. Appl Environ Microbiol 65: $2585-2591$

Wintermans JFGH, de Mots A (1965) Spectrophotometric characteristics of chlorophylls a and b and their phaeophytins in ethanol. Biochim Biophys Acta 109:448-453 